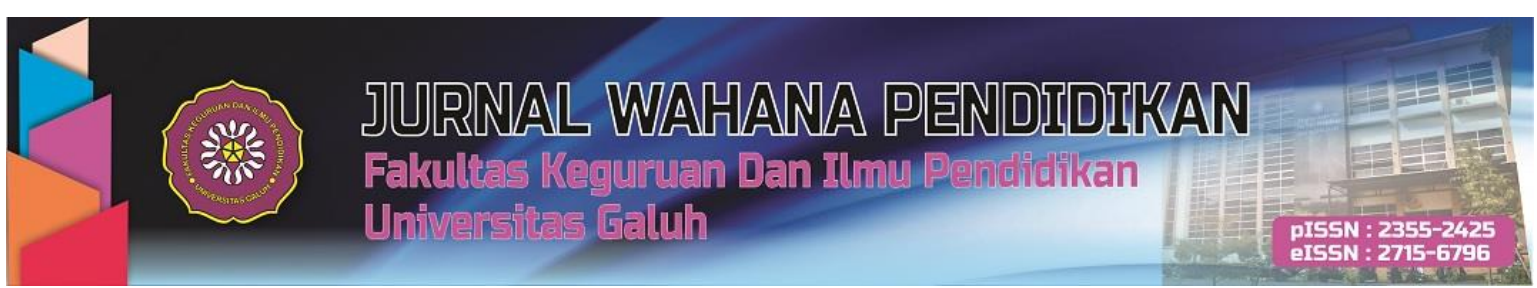

https://jurnal.unigal.ac.id/index.php/jwp

\title{
MENUMBUHKAN KEMAMPUAN BERPIKIR KRITIS SISWA MELALUI IMPLEMENTASI MODEL CONTROVERSIAL ISSUES PADA PEMBELAJARAN IPS (Penelitian tindakan kelas VIII B SMP Negeri 2 Ciamis)
}

\author{
Edi Supriadi \\ Jl. Raya Desa Baregbeg No. 209, Ciamis, Indonesia \\ Email: edisupriadi518@gmail.com
}

\begin{abstract}
The purpose of this study is to determine the critical thinking skills of students in class VIII B of SMP Negeri 2 Ciamis, Indonesia which emerged through a controversial issue model in social studies learning. This study used a qualitative and quantitative approach. 33 students in class VIII B were taken as the subject of this study. The four stages of classroom action research were planning, action, observation, and reflection which carried out in two cycles, and each cycle consists of two meetings. The data collection techniques used tests, observations, documentation, and field notes. The data analysis techniques used qualitative and quantitative descriptive analysis. The results of the study were: 1) social studies learning by means of a controversial issue model includes four steps, namely: (a) the teacher or student presented a case or issue related to the learning to be carried out, (b) the teacher made a group of students so that they were able to discuss problems or issues that had been presented. (c) the group representatives either as the defenders or the attackers of an opinion on a controversial issue, (d) then the teacher and students concluded and gave suggestions from the activity. 2) the implementation of the controversial Issue model in social studies learning could improve students' critical thinking skills. This can be seen from the average ability developed by each action reached 12.8 which was enough categories in cycle I, then changed to 16.8 which was good categories in cycle II.
\end{abstract}

Keywords: Critical Thinking, Controversial Issues, Social Studies Learning

\section{ABSTRAK}

Tujuan dari penelitian ini adalah untuk mengetahui kemampuan berpikir kritis siswa kelas VIII B SMP Negeri 2 Ciamis yang muncul melalui model controversial issues dalam pembelajaran IPS. Penelitian ini menggunakan pendekatan kualitatif dan kuantitatif dengan subjek penelitian siswa kelas VIII B SMP Negeri 2 Ciamis yang berjumlah 33 orang. Empat tahapan penelitian tindakan kelas meliputi: perencanaan, tindakan, observasi, dan refleksi. yang dilaksanakan dalam dua siklus, dan tiap siklus terdiri dari dua pertemuan. Teknik pengumpulan data menggunakan tes, observasi, studi dokumen dan catatan lapangan. Teknik analisis data menggunakan analisis deskriptif kualitatif dan kuantitatif. Hasil penelitian yang di peroleh adalah: 1) Bahwa pembelajaran IPS dengan menerapkan model controversial issue meliputi empat langkah yaitu : (a) guru atau siswa menyodorkan suatu kasus atau isu yang berkaitan dengan pembelajaran yang akan di laksanakan, (b) guru membentuk kelompok siswa agar mampu membahas masalah atau isu yang telah di sajikan. (c) perwakilan kelompok dapat menjadi pembela atau penyerang suatu pendapat tentang isu kontroversial di sertai alasan. (d) kemudian guru dan siswa menyimpulkan serta memberi saran terhadap pembelajaran yang telah terjadi. 2) Implementasi model controversial Issue dalam pembelajaran IPS mampu meningkatkan kemampuan berpikir kritis siswa. Hal ini dapat dilihat dari rata-rata kemampuan yang dikembangkan setiap tindakan mencapai 12,8 berkategori cukup pada siklus I, kemudian berubah menjadi 16,8 berkategori baik pada siklus II.

Kata kunci : Berpikir Kritis, Controversial Issues, Pembelajaran IPS

Cara sitasi:

Supriadi, E. (2020). Menumbuhkan Kemampuan Berpikir Kritis Siswa melalui Implementasi Model Controversial Issues pada Pembelajaran IPS. Jurnal Wahana Pendidikan, 7(1), 59-70. 


\section{PENDAHULUAN}

Penelitian ini berangkat dari fenomena rendahnya kemampuan siswa dalam mengemukakan pendapatnya di dalam kelas. Hal ini terlihat dalam proses pembelajaran bahwa tingkat partisipasi aktif siswa seperti bertanya, menanggapi, maupun menjawab pertanyaan menunjukkan sangat rendah, sehingga suasana kelas menjadi kelas yang pasif. Ketika guru melakukan sesi tanya jawab, para siswa kurang memberikan respon yang baik, hanya ada satu sampai dua orang saja yang merespon pertanyaan dari guru, siswa yang lain malah sibuk dengan aktivitasnya sendiri.

Demikian halnya sikap banyak orang terhadap mata pelajaran IPS itu sendiri masih menganggap remeh, tidak penting dan kurang menjanjikan untuk masa depan siswa. Wiriatmadja (2002), mengemukakan bahwa "Banyak siswa yang mengeluhkan bahwa pembelajaran IPS itu sangat membosankan karena isinya hanya merupakan hafalan saja dari tahun ke tahun, tokoh dan peristiwa sejarah saja.

Di sisi lain mata pelajaran IPS sangat berarti bagi kehidupan. Sapriya (2012) dan Saidihardjo (2005) mengatakan bahwa untuk anak jenjang SMP/MTS, pengorganisasian materi mata pelajaran IPS menganut pendekatan korelasi (correlated), artinya mata pelajaran dikembangkan dan disusun mengacu pada beberapa displin ilmu secara terbatas kemudian dikaitkan dengan aspek kehidupan nyata (factual/real) peserta didik sesuai dengan karakteristik usia, tingkat perkembangan berpikir, dan kebiasaan bersikap dan berperilaku. Dengan demikian maka pembelajaran IPS mempunyai kontribusi dalam upaya mencapai tujuan pendidikan nasional yaitu pertama, dapat mendewasakan peserta didik dalam merealisasikan dirinya (self relization) melalui penerapan pengetahuan, pemahaman, keterampilan, sikap dan nilai. Kedua, dapat mendewasakan peserta didik melalui pengembangan kemampuan dan penguasaan berbagai hal. Ketiga, lebih meningkatkan dan mempertajam kemampuan berpikir tingkat tinggi (thinking ability), kreatif, kritis dan mampu mengambil keputusan dengan tepat dan mandiri. Keempat, membantu peserta didik untuk memperoleh keterampilan sosial (social skill) seperti keterampilan berinteraksi dan beradaptasi dengan lingkungan, (Sumaatmaja, 1980; Ennis, 1985; Harjasujana, 1987).

Permasalahannya sekarang adalah apakah pendidikan IImu Pengetahuan Sosial telah mampu merangsang siswa untuk menumbuhkan kemampuan berpikir kritis? Munandar (1999) mengemukakan bahwa cara yang paling baik bagi guru untuk mengembangkan kreativitas siswa adalah dengan memberikan dorongan (motivasi) intrinsic atau ekstrinsic peserta didik. Mata pelajaran IPS bertujuan mengembangkan potensi peserta didik agar peka terhadap masalah sosial di masyarakat, memiliki sikap mental positif terhadap perbaikan segala ketimpangan yang terjadi, dan terampil mengatasi setiap masalah yang terjadi sehari-hari baik yang menimpa dirinya sendiri maupun dalam kehidupan masyarakat. (Sumaatmaja, 1980; Eggen, 1996; Paul,2005).

Salah satu pengorganisasian materi yang dianggap bisa mendorong peserta didik untuk mengembangkan kemampuan berfikir kritis adalah dengan menempatkan "Isu kontroversial" dalam pembelajaran IPS. Isu kontroversial di sini adalah merupakan isu yang banyak dijumpai dalam banyak peristiwa sosial. Materi yang terdapat dalam buku panduan siswa seringkali berbeda dengan apa yang diperoleh siswa lewat internet, bacaan referensi, dan media massa (Angkasa, 2019). Hasan (1996), pembelajaran IPS dengan model isu kontroversial, siswa diharapkan: (1) memahami dan menyadari betapa interaksi antara pelaku dengan lingkungan dan peristiwa yang ditimbulkan di dalamnya mengandung sejumlah isu dan persoalan, sehingga ada alternatif penyelesaian yang merupakan interaksi antara pelaku, (2) memberi kesempatan yang luas kepada siswa untuk berperan sebagai 
warga negara dan masyarakat berpartispasi dalam memecahkan berbagai isu di lingkungan yang terdekat dengan kehidupannya. Di tingkat awal sebaliknya pengajaran tidak terlalu mengungkapkan banyak isu yang berbeda. Dua atau tiga isu yang berbeda sudah dianggap cukup. Dalam hal ini kemampuan siswa untuk berbeda pendapat dan toleransi berpendapat merupakan tujuan (Hasan, 1996; Percivall, 1988; Roestiyah, 2008).

Pembelajaran dengan model controversial issue dapat melatih siswa untuk dapat mengembangkan dan mengasah potensi kemampuan yang ada dalam dirinya menjadi lebih peka terhadap keadaan di sekitarnya dan mampu berpikir kreatif yang didasarkan pada masalah-masalah yang mereka temui dalam kehidupan sehari-hari. Dengan demikian diharapkan melalui isu kontroversial pada pembelajran IPS dapat melatih siswa berpikir kritis. Oleh sebab itu tujuan dari penelitian ini adalah untuk mengetahui implementasi model controversial issue dalam pembelajaran IPS di kelas VIII B SMP Negeri 2 Ciamis dan mendeskripsikan tumbuhnya keterampilan berfikir kritis siswa kelas VIII B SMP Negeri 2 Ciamis melalui penerapan model controversial issue.

\section{METODE PENELITIAN}

Penelitian yang digunakan adalah Penelitian Tindakan Kelas (PTK) dengan model spiral dari Kemmis dan Taggart (1988) dan Arikunto (2006)

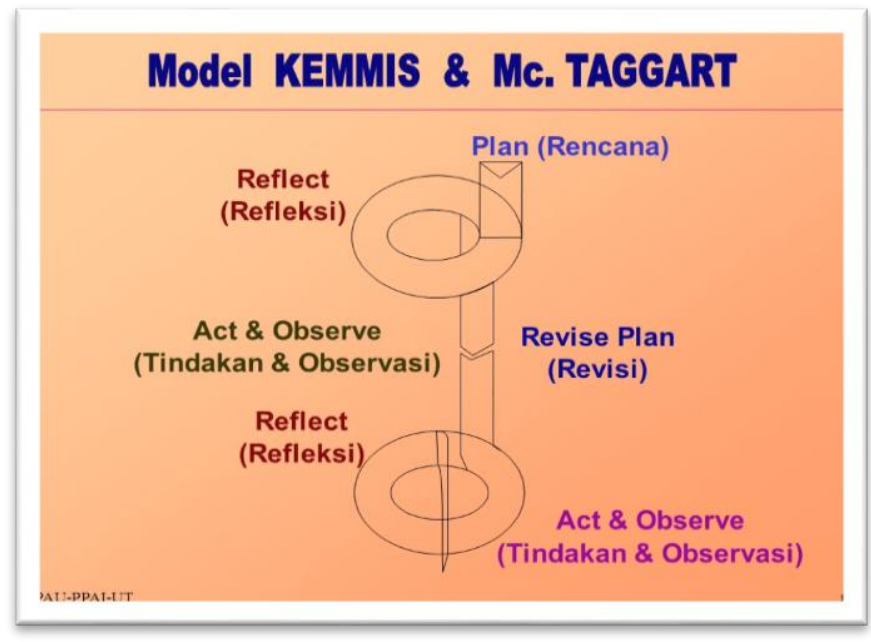

Gambar 1. Siklus Penelitian Tindakan Kelas Model Spiral dari Kemmis dan Taggart

\section{HASIL DAN PEMBAHASAN}

Muessing dalam Solihatin (2012) mengatakan bahwa Isu Kontroversial merupakan sesuatu yang mudah di terima oleh seseorang atau kelompok, tetapi juga mudah ditolak oleh orang atau kelompok lain. Wiriatmaja (2002) dan Sulistyorini (2009) mengatakan bahwa "kecenderungan seseorang atau kelompok untuk memihak didasari oleh pertimbangan pemikiran tertentu. Apabila orang tidak sependapat, atau terbentuk opini yang bertentangan dalam suatu hal, maka itulah yang disebut isu kontroversial." Wiriaatmadja (dalam Komalasari, 2010) mengemukakan langkah-langkah penerapan model controversial issue : 1). Guru beserta siswa melakukan brainstorming mengenai isu-isu kontroversial yang akan dibahas, 2).Siswa berkelompok memilih salah satu kasus untuk dikaji, 3).Siswa melakukan inkuiri, mengundang narasumber, membaca buku, mengumpulkan informasi lain, 4) Siswa menyajikan/mendiskusikan hasil inkuiri, mengajukan argumentasi, mendengarkan counter- 
argument atau opini lain, 5) Siswa menerapkan konsep, generalisasi, teori ilmu sosial untuk secara akademis menganalisis permasalahan.

Hasan dalam Saripudin (2015), sebagai berikut : 1). Guru menyajikan materi yang mengandung isu kontroversial. Penyajian ini dapat dilakukan melalui penjelasan guru, atau siswa membaca dan mendengar isu kontroversial yang telah disiapkan guru, 2) mengundang berbagai pendapat disertai argumentasi dari siswa mengenai isu tersebut. Pendapat-pendapat yang berbeda diidentifikasi sebagi isu kontroversial, 3) Isu kontroversial yang teridentifikasi dijadikan behan diskusi. Setiap orang dapat menjadi pembela dan penyerang suatu pendapat.

Berdasarkan hal tersebut, langkah-langkah model Cotroversial Issue meliputi : 1) Adanya kasus atau isu yang berkaitan dengan pembelajaran, 2) kelompok siswa 3) Dalam kelompok dapat menjadi pembela atau penyerang suatu pendapat disertai alasan. 4) guru dan siswa menyimpulkan dan memberi saran terhadap pembelajaran yang telah terjadi. Komalasari (2010), bahwa fungsi dan tujuan model Isu Kontroversial yaitu :

a. Meteri isu kontroversial secara langsung membangkitkan kemampuan berpikir seseorang;

b. Mengembangkan pendapat baru yang lebih baik, sehingga terjadi proses analogis dan sintesis dalam berpikir;

c. Melatih siswa : a) membuat hipotesis, mengumpulkan evidensi, menganalisis data, dan menyajikan hasil inkuiri; b) menghadapi kehidupan sosial yang kompleks dengan keterampilan berkomunikasi, menanamkan rasa empati, mempengaruhi orang lain, toleran, berkeja sama, dan lain-lain; c) mempelajari studi kasus dengan memahami penggunaan konsep, generalisasi, dan teori ilmu-ilmu sosial (Wiriaatmadja, 2002).

Berdasarkan teori tersebut dapat di simpulkan bahwa fungsi dan tujuan model Controversial Issue adalah "membantu membangkitkan kemampuan berpikir siswa sehingga tujuan pembelajaran dapat terlaksana". Keunggulan model Controversial Issue menurut Wiriaatmadja (dalam kokom komalasari, 2010) antara lain :(a) Mengajarkan kepada siswa keterampilan akademis untuk membuat hipotesis, mengumpulkan evidensi, menganalisis data, dan menyajikan hasil inkuiri; (b) Melatih siswa untuk menghadapi kehidupan sosial yang kompleks dengan keterampilan berkomunikasi, menanamkan rasa empati, memengaruhi orang lain, toleran, bekerja sama, dan lain-lain; (c) Karena isu-isu yang dibahas berguna untuk mempelajari studi kasus dengan memahami penggunaan konsep, generalisasi, dan teori ilmu-ilmu sosial.

Solihatin (2012) mengemukakan bahwa :"Keuntungan model pembelajaran Isu Kontroversial adalah melalui pendapat yang berbeda orang dapat mengembangkan pendapat baru yang lebih baik. Di sini terjadi proses analogis, sintensis dalam berpikir. Dengan demikian dapat dikatakan bahwa kelebihan model pembelajaran Controversial Issue adalah adanya pendapat yang berbeda-beda akan memberikan wawasan dan meningkatkan kemampuan berpikir siswa sehingga tujuan pembelajaran dapat tecapai dengan baik.

Sebaliknya, kekurangan model pembelajaran Controversial Issue sebagaimana Lickona (2012) mengemukakan bahwa:"Mengingat menjadi moderator yang adil tidaklah mudah ketika seseorang guru memiliki perasaan yang kuat terhadap sebuah isu kontroversi. Hal tersebut membutuhkan komitmen yang tidak tergesa-gesa dari guru agar tidak berpihak pada salah satu pihak. Guru dapat menolong siswa sebagai moderator yang netral jika mereka mengemukakan keberpihakan mereka pada awal diskusi.

Solihatin (2012) mengemukakan kekurangan bahwa:(a).Isu Kontroversial tidak boleh menimbulkan pertentangan suku, agama dan ras; (b).Isu Kontroversial sebaiknya dekat dengan 
kehidupan mahasiswa masa kini; (c).Isu Kontroversial sebaiknya sesuatu yang sudah menjadi milik masyarakat; (d).Isu Kontroversial seyogianya berkenaan dengan masalah setempat, nasional maupun internasional.

Maka antisipasinya guru bersikap netral saat menjadi moderator, tidak mementingkannya sendiri dan disajikan dengan menarik. Tumbuhnya keterampilan berfikir kritis siswa kelas VIII B SMP Negeri 2 Ciamis melalui penerapan model controversial issue diteliti dengan menggunakan metode PTK yang terdiri dari dua siklus.

\section{Siklus I}

Pelaksanaan siklus I dilaksanakan dua kali pertemuan yaitu pada tanggal 14 dan 21 September 2017 dengan alokasi waktu 4 × 40 menit, dengan tahapan perencanaan, pelaksanaan tindakan, pengamatan dan refleksi.

\section{Perencanaan}

Pertama: peneliti melakukan studi pendahuluan terhadap materi yang akan disampaikan dan metode yang akan diterapkan. Kedua: Memberikan kesempatan kepada setiap kelompok untuk berdiskusi, yakni memunculkan masalah-masalah sekitar penduduk. Beri stimulus kepada mereka agar mencari masalah-masalah yang dekat dengan kehidupan mereka agar masalah tersebut kontekstual dan bermakna bagi kehidupan praktis mereka. Ketiga: Setiap kelompok melakukan investigasi dan inquiri masalah melalui kajian terhadap berbagai buku referensi atau melihat realitas sosial yang dekat dengan kehidupan mereka. Keempat: Mereka diberi kesempatan untuk melakukan presentasi hasil.

\section{Pelaksanaan}

Tindakan yang dilaksanakan pada siklus I ini merupakan realisasi dari perencanaan tindakan yang telah disusun meliputi kegiatan pertama tanggal 14 dan kegiatan kedua tanggal 21 September 2017. Setiap pelaksanaan tindakan dalam kegiatan tatap muka dilakukan observasi. Observasi dilakukan oleh observer kolaborasi Ibu Ine Anggraeni, S.Pd.(pengajar IPS) terhadap pengajar (penulis) di kleas VIIIB.

\section{Pengamatan}

Peneliti melakukan observasi terhadap keterampilan guru dan kemampuan siswa dalam berfikir kritis selama proses pembelajaran IPS dalam dua pertemuan melalui penerapan model controversial issue di kelas VIII B dengan lembar observasi yang telah disiapkan. Hasil observasi disajikan dalam grafik keterampilan guru pada gambar 2

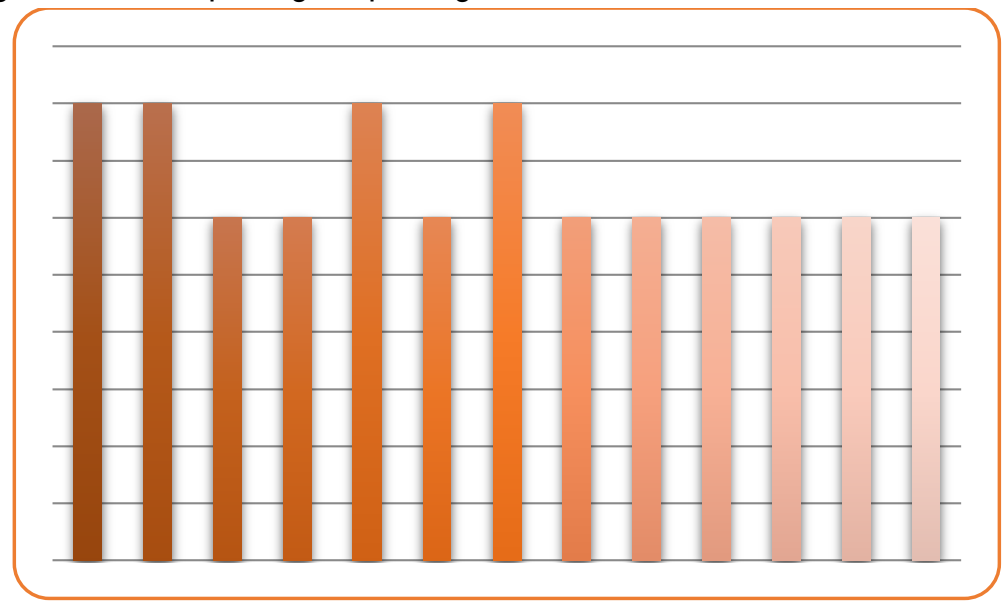

Gambar 2. Grafik Hasil Observasi Aktivitas Guru Siklus I 
Selanjutnya observer melakukan pengamatan terhadap aktivitas siswa selama proses pembelajaran terutama mengenai keterampilan kemampuan birfikir kritis saat diskusi kelompok maupun presentasi di depan kelas. observasi tersebut meliputi lima indikator yang dikembangkan yaitu kemampuan mendefinisikan masalah, kemampuan menyeleksi informasi untuk pemecahan masalah, kemampuan mengenali asumsi-asumsi, kemampuan merumuskan hipotesis, dan kemampuan menarik kesimpulan diperoleh rata-rata 12,8 atau termasuk kategori cukup. Untuk lebih jelasnya data tersebut dapat disajikan dalam sebuah grafik gambar 3

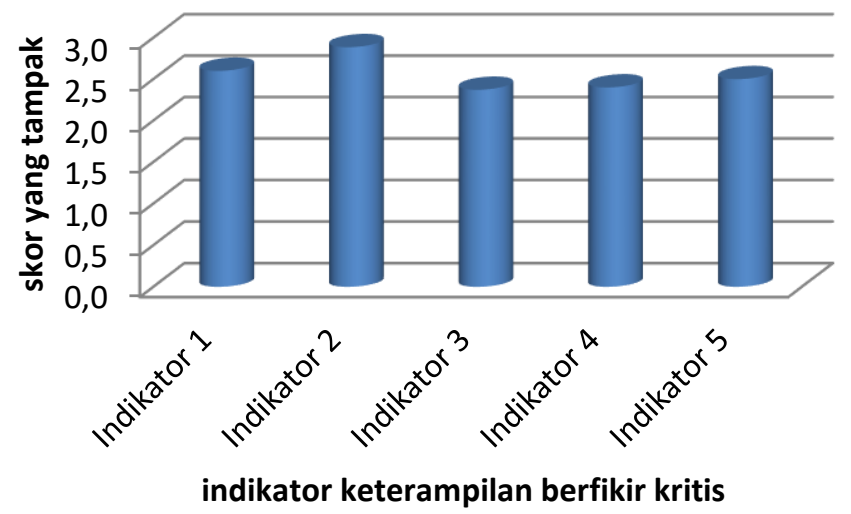

Gambar 3. Grafik Nilai rata-rata Keterampilan Berfikir Kritis Siklus I

Di akhir pertemuan siklus I peneliti melakukan sebuah tes tes tulis essay sebanyak 5 nomor. Berdasarkan hasil analisis penilaian maka pada siklus I ini diperoleh nilai rata-rata secara klasikal sebesar 79,7 dengan persentase ketuntasan sebesar 69,7\% dan persentase tidak tuntas sebesar $30,3 \%$. Sehingga secara keseluruhan dapat disimpulkan bahwa pelaksanaan siklus I belum berhasil memenuhi target, untuk lebih jelasnya dapat dilihat pada grafik berikut.

\section{Refleksi}

Secara umum, pembelajaran menggunakan model controversial issue dapat berlangsung dengan cukup baik sesuai yang ditunjukkan dari hasil tes dan non tes yang telah dikemukakan di atas. Walaupunu masih ada beberapa siswa yang belum cukup terlibat aktif dalam kegiatan. Hal ini karena penerapan model controversial issue baru pertama kali sehingga belum terbiasa dengan kegiatan yang membutuhkan keaktifan (menggali masalah, menemukan solusi, dan sebagainya).

\section{Siklus II}

Pelaksanaan siklus II dilaksanakan dua kali pertemuan yaitu pada tanggal 28 September dan 5 Oktober 2017 dengan alokasi waktu 4 x 40 menit, dengan tahapan perencanaan, pelaksanaan tindakan, pengamatan dan refleksi. Berikut pelaksanaan pada kegiatan siklus II

\section{Perencanaan}

Rencana tindakan pada siklus II ini ada beberapa tambahan tindakan yakni bagaimana memberikan solusi terhadap beberapa siswa yang tidak aktif dan 'cuek' terhadap kegiatan pembelajaran. Tambahan itu bisa dua kemungkinan tindakan, yakni: pertama, siswa-siswa yang terekam tidak aktif atau hanya 'cuek' dalam kegiatan pembelajaran dengan model controversial issue ini dikelompokkan tersendiri, dengan maksud agar mereka termotivasi untuk menyelesaikan tugas yang dibebankan kepadanya. Kedua, mendasarkan diri pada teori Multiple Intelligences, dimana kemungkinan siswa yang tidak terlibat aktif tersebut adalah siswa yang memiliki kecenderungan 
cerdas intrapersonal (senang bekerja individual) dan lemah dalam interpersonal (kerja sama dengan teman), maka memberikan tugas kepada siswa-siswa tersebut secara individual perlu dicoba.

\section{Pelaksanaan}

Pertemuan pertama dilaksanakan pada hari Selasa, 28 September 2017. Selanjutnya peneliti membagi siswa menjadi beberapa kelompok belajar secara heterogen dengan maksud supaya terjadi pemeratan baik sisi gender maupun kemampuan ditambah dengan pengelompokan yang acuh pada pembelajaran siklus sebelumnya. Pada pertemuan kedua, penelitian dilaksanakan pada tanggal 5 Oktober 2017 jam ke-3 samapi jam ke-4. pukul 08.20 sampai dengan pukul 09.40 .

\section{Pengamatan}

Peneliti melakukan observasi terhadap Ibu Ine Anggraeni, S.Pd. dengan fokus pada keterampilan guru dan kemampuan siswa dalam berfikir kritis melalui penerapan model controversial issue menggunakan lembar observasi yang telah disiapkan. Hasil observasi meliputi keterampilan guru selama proses pembelajaran IPS melalui penerapan model controversial issue diperoleh skor 48, dengan rata-rata 3,7 kategori sangat baik.

Pada akhir tindakan siklus II dalam hal ini pertemuan kedua guru memberikan evaluasi dengan hasil keterampilan memberikan evaluasi memperoleh skor 3 . Soal berupa essay. Berikut ini adalah grafik keterampilan guru dalam pembelajaran IPS melalui penerapan model controversial issue.

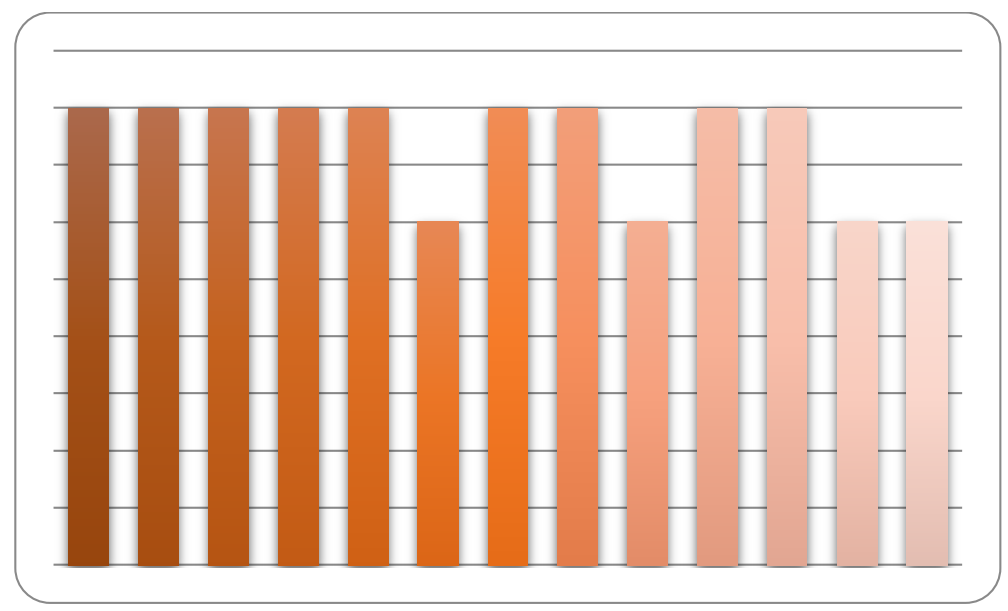

Gambar 4. Grafik 4.4. Hasil Observasi Aktivitas Guru Siklus II

Selanjutnya obvservasi terhadap terhadap jalannya aktivitas siswa selama proses pembelajaran terutama mengenai keterampilan kemampuan birfikir kritis saat diskusi kelompok maupun presentasi di depan kelas dengan hasil dari lima indikator yang dikembangkan diperoleh ratarata 16,8 atau termasuk kategori baik. Kemampuan mendefinisikan masalah dari keseluruna jumlah siswa secara klasikal diperoleh rata-rata 3.4. Disini siswa mayoritas mampu mendefinisikan permasalahan yang diberikan. Kemampuan menyeleksi informasi untuk pemecahan masalah secara keseluruhan siswa baik karena apabila dilihat dari rata-rata secara klasikal diperoleh nilai 3.4. Selanjutnya kemampuan mengenali asumsi-asumsi dari pernyataan yang diberikan juga hanya diperoleh rata-rata sebesar 3.2, hal ini masih ada beberapa siswa yang kurang mampu memunculkan idenya. Kemampuan merumuskan hipotesis diperoleh rata-rata 3.4. artinya siswa nampak mampuh membuat sebuah hipotesis dari permasalahan yang dimunculkan dalam materi yang diberikan. Indikator yang terakhir yaitu kemampuan menarik kesimpulan, disini siswa secara garis besar mampu membuat suatu kesimpulan secara mandiri maupun kelompok karena berdasarkan hasil penilaian 
diperoleh rata-rata secara kasikal sebesar 3.4.Untuk lebih jelasnya data tersebut dapat disajikan dalam sebuah grafik berikut.

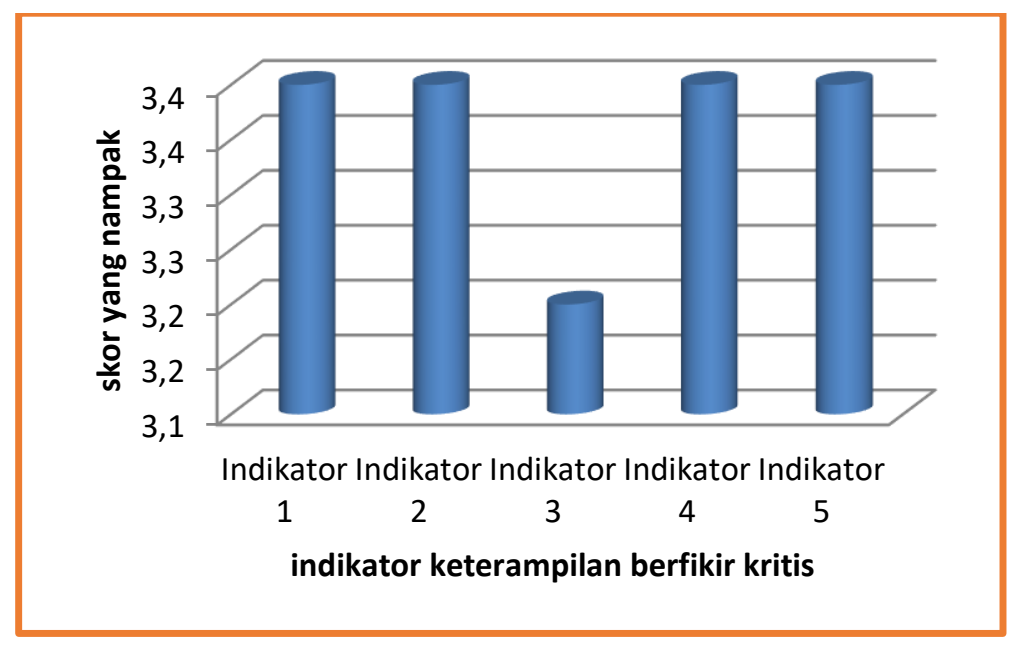

Gambar 5. Grafik Nilai rata-rata Keterampilan Berfikir Kritis Siklus II

Pada pelaksanaan siklus kedua terlihat adanya peningkatan yang sangat baik dibuktikan dengan sebagian besar siswa terlibat langsung dalam pembelajaran IPS, mampu memecahkan sendiri permasalahan yang ada saat pembeljaran di kelas, berani mengemukakan pendapat didepan kelas, mampu menyanggah pendapat orang lain dan sudah mulai berpikir kritis tentang materi IPS.

Pada pertemuan akhir siklus II, peneliti melakukan sebuah tes evaluasi belajar dengan maksud melihat keberhasilan pelaksanaan pembelajaran dalam penguasaan konsep materi yang telah diberikan. Tes tersebut berupa tes tulis dengan bentuk soal essay sebanyak 5 nomor. Berdasarkan hasil analisis penilaian maka pada siklus II ini diperoleh nilai rata-rata secara klasikal sebesar 87,7 dengan persentase ketuntasan sebesar $97,0 \%$ dan persentase tidak tuntas sebesar 3,0 $\%$. Sehingga secara keseluruhan dapat disimpulkan bahwa pelaksanaan siklus II berhasil memenuhi targel ketentuan untuk lebih jelasnya dapat dilihat pada grafik berikut.

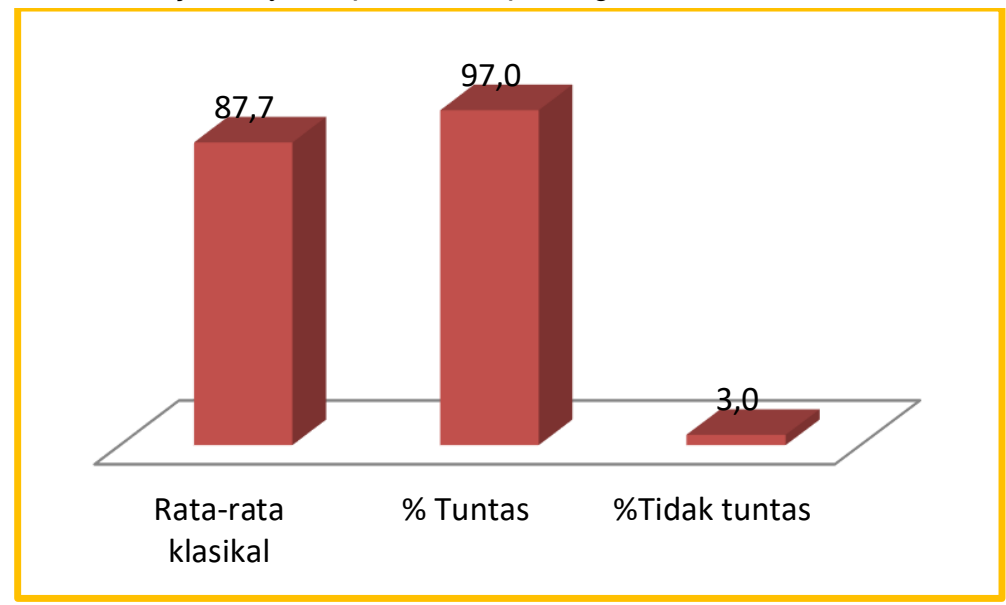

Gambar 6. Grafik Hasil Evaluasi Belajar Siswa Siklus II

\section{Refleksi}

Prestasi akademik yang ditunjukkan dari nilai tes mengalami kenaikan yang cukup signifikan. Demikian juga kemampuan berfikir kritis juga mengalami kenaikan. Tampaknya, siswa-siswa sudah mulai terbiasa dengan bekerja sama dalam belajar (kooperatif learning) model controversial issue. Beberapa siswa yang masih tampak ogah-ogahan dalam melakukan kegiatan di siklus I, pada siklus 
II ini diberikan tugas individual, ternyata mereka bisa menyelesaikan tugasnya itu dengan baik. Anakanak tersebut termasuk intrapersonal (cerdas diri) dan lemah dalam interpersonal (kerja sama).

Berdasarkan pendapat yang di kemukakan di atas bahwa penerapan model Controverssial Issues ini mampu mengembangkan kemampuan berpikir siswa, meningkatkan kemampuan siswa untuk mengharhgai pendapat orang lain, indikator pencapain tersebut telah di buktikan pada saat melakukan penelitian di kelas VIII B.

a. Peningkatan Keterampilan Guru dalam Mengelola Pembelajaran.

Gambar 7 memperlihatkan capaian peningkatan hasil aktifitas guru selama pembelajaran berlangsung di kelas. Grafik tersebut memberikan informasi selama pembelajaran siklus satu dan dua ada yang tetap dan ada yang meningkat.

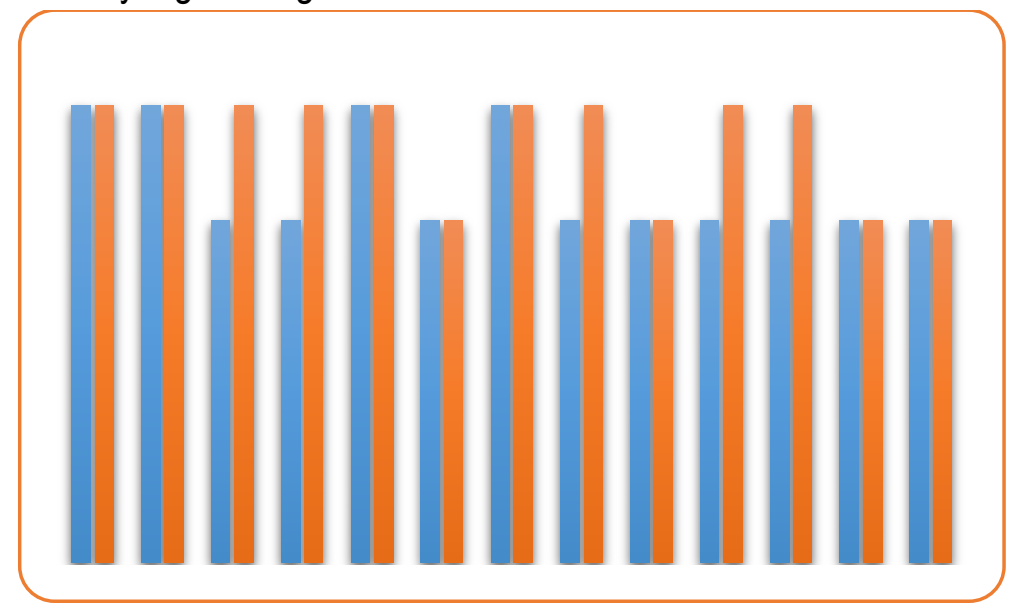

Gambar 7. Grafik Peningkatan Hasil Aktivitas Guru dalam Pembelajaran

b. Peningkatan Kemampuan Berfikir Kritis Siswa dalam Pembelajaran

Gambar 8 menunjukan semua indikator kemampuan berfikir kritis siswa selama pembelajaran dari mulai siklus pertama sampai kedua memiliki peningkatan yang signifikan.

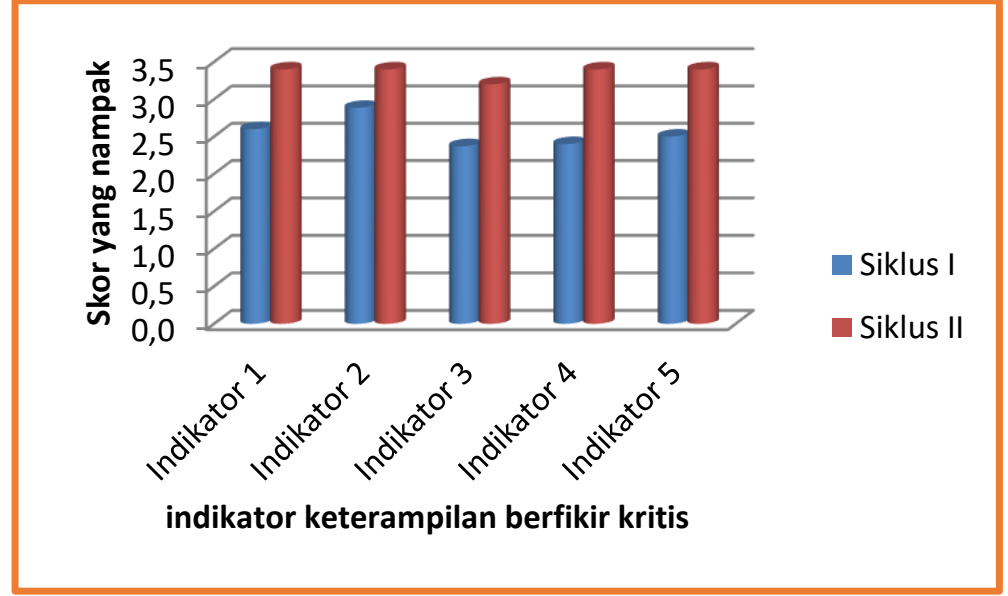

Gambar 8. Grafik Peningkatan Nilai rata-rata Keterampilan Berfikir Kritis

\section{c. Peningkatan Hasil Evaluasi Belajar}

Gambar 9 menunjukan peningkatan rata-rata klasikal siswa dan ketuntasan siswa selama pembelajaran menggunakan model controversial issues pada pembelajaran IPS. Hal ini menunjukan bahwa model pembelajaran model controversial issues dapat meningkatkan hasil belajar siswa. 


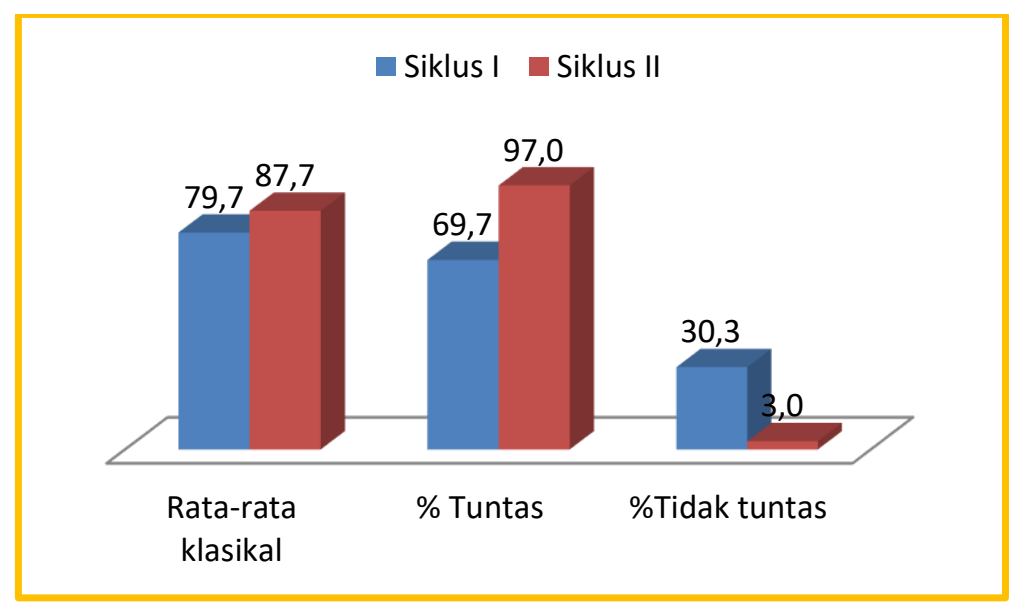

Gambar 9. Grafik Peningkatan Hasil Evaluasi Belajar

Maka disini dapat kita katakan, kemampuan berpikir ktitis itu terdiri atas (1) kemampuan mendefinisikan masalah, (2) kemampuan menyeleksi informasi untuk pemecahan masalah, (3) kemampuan mengenali asumsi-asumsi, (4) kemampuan merumuskan hipotesis, dan (5) kemampuan menarik kesimpulan.

\section{KESIMPULAN}

Dari hasil pemaparan dan analisis data maka dapat disimpulkan bahwa pembelajaran IPS menggunakan model controversial issue meliputi empat langkah yaitu 1) guru atau siswa menyodorkan suatu kasus atau isu yang berkaitan dengan pembelajaran yang akan di laksanakan, 2) guru membentuk kelompok siswa agar mampu membahas masalah atau isu yang telah di sajikan. 3 ) perwakilan dari kelompok dapat menjadi pembela atau penyerang suatu pendapat tentang isu kontroversial di sertai alasan. 4) kemudian guru dan siswa menyimpulkan dan memberi saran terhadap pembelajaran yang telah terjadi. Selanjutnya diperoleh hasil bahwa implementasi model controversial Issue dalam pembelajaran IPS mampu meningkatkan kemampuan berpikir kritis siswa. Hal ini dapat di lihat dari hasil rata-rata kemampuan yang dikembangkan dalam tiap tindakan yaitu 12,8 atu kategori cukup untuk siklus I berubah menjadi 16,8 atau kategori baik pada siklus II.

\section{REKOMENDASI}

Peneliti selanjutnya dapat mengimplementasi model pembelajaran yang lain selain model pembelajaran controversial issue dan mendeskripsikan tumbuhnya keterampilan berfikir tingkat tinggi lainnya.

\section{UCAPAN TERIMAKASIH}

Peneliti mengucapkan terimakasih kepada pihak-pihak yang telah membantu dalam kegiatan penelitian yang dilakukan yaitu pihak sekolah SMP Negeri 2 Ciamis, guru mata pelajaran IPS kelas VIII B kelas IPS dan siswa kelas VIII B kelas IPS.

\section{DAFTAR PUSTAKA}

Angkasa, A., Rusyana, A., \& Erlin, E. (2019). Penerapan model pembelajaran open ended problems terhadap peningkatan kemampuan berpikir kritis. Jurnal Wahana Pendidikan, 5(2), 1-4.

Arikunto, S. (2006). Prosedur Penelitian: Suatu Pendekatan Praktik, Jakarta: PT Rineka Cipta. 
BSNP. 2006. Kurikulum Satuan Tingkat Pendidikan. Jakarta: Depdiknas.

Eggen, P. D. \& Kauchak, D. P. (1996). Strategies for Teacher: Teaching Content and Thinking Skills. Boston: Allyn \& Bacon.

Ennis, R. H. (1985). Goals For A Critical Thinking Curriculum, Developing Minds: A Resource Book For Teaching Thinking.Virginia: ASCD.

Harjasujana. (1987)."Membaca 2”. Jakarta: Departemen Pendidikan dan Kebudayaan.

Hasan. (1996). Pendidikan IImu-IImu Sosial. Bandung: Jurusan Sejarah IKIP.

Kemmis, S., \& Taggart, R. (1988). The Action Planner (Geelong, Deakin University Press).

Komalasari, K. (2010). Pembelajaran Kontekstual Konsep dan Aplikasi. Bandung : PT. Refika Aditama

Lickona, T. (2012). Educating for character: Mendidik untuk membentuk karakter. Jakarta: Bumi Aksara.

Munandar, U. (1999). Kreativitas Dan Keberbakatan: Strategi Mewujudkan Potensi Kreatif dan Bakat. Jakarta : Gramedia Pustaka Utama.

Paul, Richard \& Elder, L. (2005). The Miniature Guide to Critical Thinking "CONCEPTS \& TOOLS". The Foundation of Critical Thinking. California.

Percivall \& Ellington (1988). Teknologi Pendidikan. Jakarta : Erlangga.

Roestiyah. (2008). Stategi Belajar Mengajar.Jakarta:PT. Rineka Cipta.

Saidihardjo. (2005). Konsep Dasar Ilmu Pengetahuan Sosial. Yogyakarta: FIP IKIP Yogyakarta.

Sapriya. (2012). Pendidikan IPS Konsep dan pembelajaran. Bandung : PT Remaja Rosdakarya Offset.

Saripudin, D., \& Komalasari, K. (2015). Living values education in school's habituation program and its effect on student's character development. The New Educational Review, 39(1), 51-62.

Solihatin, E. (2012). Cooperative Learning, Analisis Model PembelajaranIPS. Jakarta: Penerbit Bumi Aksara.

Sulistyorini. (2009). Evaluasi Pendidikan: dalam Meningkatkan Mutu Pendidikan, Yogyakarta: TERAS

Sumaatmaja. (1980). Metodologi Pengajaran IImu Pendidikan Sosial, Bandung : Alumni. 
Wiriaatmadja, R. (2002). Pendidikan Sejarah di Indonesia: Perspektif Lokal, Nasional, dan Global. Historia Utama Press, Jurusan Pendidikan Sejarah FPIPS, Universitas Pendidikan Indonesia. 